\title{
Vase Life Attributes of Gladiolus primulinus cv. Candyman: Influence of Pre Harvest Treatments
}

\author{
Nini R. Kuotsu*, Rokolhuii Keditsu, Laishram Hemanta, \\ K.S. Sabastian and Jonah Dakho
}

Department of Horticulture, School of Agricultural Sciences and Rural Development,
Nagaland University, Medziphema- 797106, Nagaland, India

*Corresponding author

\section{A B S T R A C T}

\section{Keywords}

Gladiolus, Pre

harvest treatments, Vase life

Article Info

Accepted:

15 June 2018

Available Online:

10 July 2018
Present experiment was carried out in the Experimental Farm, Department of Horticulture, School of Agricultural Sciences and Rural Development, Nagaland University, Medziphema Campus during 2014-15 and 2015-16 to study the response of pre harvest treatments on vase life attributes of Gladiolus primulinus cv. Candyman. The experiment was laid out in RBD with 14 treatments and 3 replications. The treatments were $\mathrm{T}_{0}$ (Control), $\mathrm{T}_{1}\left(\mathrm{FYM} 40 \mathrm{t} \mathrm{ha}^{-1}\right), \mathrm{T}_{2}$ (Pig manure $35 \mathrm{t} \mathrm{ha}^{-1}$ ), $\mathrm{T}_{3}$ (Vermicompost $10 \mathrm{t} \mathrm{ha}^{-1}$ ), $\mathrm{T}_{4}$ (NPK 100\% RDF i.e. 200:200:200 kg NPK ha ${ }^{-1}$ ); $\mathrm{T}_{5}$ (Azospirillum + Phosphotica), $\mathrm{T}_{6}$ $(50 \% \mathrm{NPK}+50 \% \mathrm{FYM}), \mathrm{T}_{7}(50 \% \mathrm{NPK}+50 \% \mathrm{Pig}$ manure $), \mathrm{T}_{8}(50 \% \mathrm{NPK}+50 \%$ Vermicompost), $\mathrm{T}_{9}$ (50\% NPK + Azospirillum + Phosphotica), $\mathrm{T}_{10}$ (75\% NPK + Azospirillum + Phosphotica), $\mathrm{T}_{11}(50 \% \mathrm{NPK}+25 \%$ FYM + Azospirillum + Phosphotica), $\mathrm{T}_{12}\left(50 \% \mathrm{NPK}+25 \%\right.$ Pig manure + Azospirillum + Phosphotica) and $\mathrm{T}_{13}(50 \% \mathrm{NPK}+$ $25 \%$ Vermicompost + Azospirillum + Phosphotica). Pooled data revealed that $\mathrm{T}_{12}$ recorded the highest fresh weight $(65.37 \mathrm{~g})$, water uptake $(21.41 \mathrm{~g})$, water loss $(17.06 \mathrm{~g})$ and water balance ratio (1.263) on the $3^{\text {rd }}$ day of vase life. Maximum days to drooping of the $1^{\text {st }}$ floret (4.86) and $5^{\text {th }}$ floret $(8.46)$, maximum florets to remain open at a specific time (6.34) and longest vase life (12.51 days) were also observed in the same treatment.

\section{Introduction}

Gladiolus is universally acclaimed prestigious flower. It has a great economic value as a cut flower and is known as queen amongst the bulbous flowers. Commercial cultivation of gladiolus is ever increasing due to its vivid colour, shape, size and long durability of spike in holding solution. It occupies the fourth place in international cut flower trade
(Bhattacharjee and De, 2010). It has second rank after tulip among the bulbous flowers in India (Singh et al., 2012). Gladioli contribute the most important item for aesthetic, economic and social appeal. Florets open sequentially from the base of the rachis and extension of longevity of these florets helps in maintaining the economic value of these flowers for a longer time. The cut spikes to sustain floret longevity in an acceptable 
condition after harvest, is the criterion for describing the keeping quality of the flower which largely depends on the food materials supplied during growth as well as food sources in vase solution. One of the most effective means to improve the quality and longevity of flower spikes in a sustainable production system is by adopting proper nutrient management practices by making judicious use of inorganic fertilizers, manures, composts and biofertilizers alone or in combination to get quality products without environmental hazard. The North Eastern Region of India, due to its peculiar physiographic, distinctive weather has the agro climatic advantage of tropical and temperate regions to grow varieties of floriculture crops in addition to rich genetic diversity. Nagaland has the suitable agroclimatic conditions which clearly indicate that wide range of ornamental crops can be grown, which can improve the economic conditions of the growers due to their higher income per unit area. Realizing the potential of this sector, many budding entrepreneurs are taking up floriculture. Thus, there is immense need to generate sufficient information on various parameters on this aspect. Keeping in view the above facts, an investigation was carried out to evaluate the response of pre harvest treatments on the vase life attributes of Gladiolus primulinus cv. Candyman.

\section{Materials and Methods}

A field experiment was carried out to evaluate the response of pre harvest treatments on vase life attributes of Gladiolus primulinus cv. Candyman in the Experimental farm of Horticulture, Nagaland University, School of Agricultural Sciences and Rural Development, Medziphema Campus, Nagaland during 20142016. The soil type of the experimental site was sandy loam having a $\mathrm{pH}$ of 4.75 , organic carbon $1.74 \%$, available $\mathrm{N}, \mathrm{P}$ and $\mathrm{K}$ of 240.8 , 17.12 and $219.4 \mathrm{~kg} \mathrm{ha}^{-1}$ respectively. The experiment consisted of fourteen treatments replicated three times in a randomized block design. The treatments were $\mathrm{T}_{0}$ (Control), $\mathrm{T}_{1}$ $\left(\right.$ FYM $\left.40 \mathrm{t} \mathrm{ha}^{-1}\right), \mathrm{T}_{2}$ (Pig manure $\left.35 \mathrm{t} \mathrm{ha}^{-1}\right), \mathrm{T}_{3}$ (Vermicompost $10 \mathrm{t} \mathrm{ha}^{-1}$ ), $\mathrm{T}_{4}$ (NPK $100 \%$ RDF i.e. 200:200:200 kg NPK ha $\left.{ }^{-1}\right) ; \mathrm{T}_{5}$ (Azospirillum + Phosphotica), $\mathrm{T}_{6}(50 \%$ NPK $+50 \% \mathrm{FYM}), \mathrm{T}_{7}(50 \% \mathrm{NPK}+50 \% \mathrm{Pig}$ manure), $\quad \mathrm{T}_{8} \quad(50 \% \quad \mathrm{NPK}+50 \%$ Vermicompost), $\mathrm{T}_{9}(50 \% \mathrm{NPK}+$ Azospirillum + Phosphotica), $\mathrm{T}_{10} \quad(75 \%$ NPK + Azospirillum + Phosphotica), $\mathrm{T}_{11}(50 \%$ NPK $+25 \%$ FYM + Azospirillum + Phosphotica), $\mathrm{T}_{12}(50 \%$ NPK $+25 \%$ Pig manure + Azospirillum + Phosphotica) and $\mathrm{T}_{13}(50 \%$ $\mathrm{NPK}+25 \%$ Vermicompost + Azospirillum + Phosphotica). The $100 \%$ recommended dose of fertilizer for gladiolus was 200:200:200 kg $\mathrm{ha}^{-1}$ available $\mathrm{N}, \mathrm{P}$ and $\mathrm{K}$, respectively. The sources of $\mathrm{N}, \mathrm{P}_{2} \mathrm{O}_{5}$ and $\mathrm{K}_{2} \mathrm{O}$ as urea, SSP and MoP were applied, respectively. The entire amounts of SSP and MoP were applied during September at the time of final bed preparation. For the treatment combinations which consisted of organic nutrient sources, the required amount were worked out with respect to available $\mathrm{N}$ content of organic nutrient sources. The nutrient profiling for the various organic nutrient sources under study are as follows- FYM: $0.5 \%, 0.4 \%$ and $0.5 \%$; pig manure: $0.6 \%, 0.7 \%$ and $0.5 \%$ and vermicompost: $2.0 \%, 1.0 \%$ and $0.7 \% \mathrm{~N}, \mathrm{P}$ and $\mathrm{K}$ respectively. Manures were applied by incorporating into the soil two weeks prior to planting. Nitrogen was applied in three equal installments at 15, 30 and 45 days after sowing. Biofertilizers were inoculated to the corms before planting by corm dip method for 30 minutes and shade dried prior to planting. Standard package of practices were followed to grow gladiolus crop. Three spikes were harvested from each plot when the first floret was half open and brought to the laboratory for post harvest studies at room temperature. The spikes were given a uniform cut of $75 \mathrm{~cm}$ and kept in a standard solution of Sucrose 
(4\%) and of $\mathrm{Al}_{2}\left(\mathrm{SO}_{4}\right)_{3}$ (300 ppm) for further post harvest studies. The various vase life parameters were recorded at every two days interval and the average values of the three spikes for every parameter were recorded. The data collected from the experiment were subjected to analysis of variance technique (ANOVA) for Randomized Block Design (Panse and Sukhatme, 1989) and the treatment variance was tested against error variance by applying Fischer Snedecor ' $F$ ' tests of probability at 5 percent level.

\section{Results and Discussion}

The results on vase life parameters as influenced by the pre harvest treatments envisaged that most of the attributes exhibited significant variation.

\section{Changes in fresh weight of spikes during vase life}

The data related to changes in fresh weight of spikes presented in Table 1 indicated that the impact was quite apparent in different treatments. In general, there was a sharp increase in the fresh weight of spikes in all the treatments on the $3^{\text {rd }}$ day of vase life which gradually decreased thereafter. The cut spikes harvested from the plots receiving integrated nutrient treatments recorded the highest fresh weight during vase life during both the years of experiment and also in pooled analysis. The pooled data analysis of two years indicated that the cut spikes harvested from the plots receiving integrated use of nutrient sources recorded the maximum fresh weight on the $3^{\text {rd }}$ day of vase life. $\mathrm{T}_{12}(50 \% \mathrm{NPK}+25 \%$ Pig manure + Biofertilizers) recorded the highest fresh weight $(65.37 \mathrm{~g})$ which showed at par readings with $\mathrm{T}_{11}(50 \% \mathrm{NPK}+25 \% \mathrm{FYM}+$ Biofertilizers) $(64.72 \mathrm{~g})$ and $\mathrm{T}_{7}(50 \% \mathrm{NPK}+$ $50 \%$ Pig manure) (64.05 g). The lowest fresh weight (41.88 g) was observed with control and $\mathrm{T}_{5}$ (Biofertilizers) (43.93 $\mathrm{g}$ ) on the $9^{\text {th }}$ day which are also at par with each other. According to the results, it is inferred that the pre harvest treatments had profound effect on the post harvest life of crop as the treatments which performed better in the field has also performed better in post harvest studies. The fresh weight might have increased as a result of the biological fixation of phosphorous and nitrogen in the portion of roots in the plants which resulted in better absorption of more nutrients and better utilization of them as well. In addition, Azospirillum plays a role in the fixation of nitrogen and is also a part of the production of GA, IAA and cytokinin like substances which improves the growth of plants. These results are on the same page with the results of Rajesh et al., (2006) who founded that applying bio-fertilizers like phosphate solubilizing bacterium and Azospirillum increased the fresh weight of flowers in carnation

\section{Water uptake}

Table 2 proved that the water uptake of cut spikes was significantly affected by the applications of various nutrient sources. In general, water uptake was greatest on the $3^{\text {rd }}$ day of vase life which gradually decreased in the following days of observation. According to the pooled analysis of the two years, $\mathrm{T}_{12}$ $(50 \% \mathrm{NPK}+25 \%$ Pig manure + Biofertilizers) recorded $21.41 \mathrm{~g}$ water uptake on the $3^{\text {rd }}$ day of vase life which was higher than all the other treatments however it was at par with $\mathrm{T}_{11}(50 \% \mathrm{NPK}+25 \% \mathrm{FYM}+$ Biofertilizers) (21.26 g) and $\mathrm{T}_{7}(50 \% \mathrm{NPK}+$ $50 \%$ Pig manure) (20.94 g), $\mathrm{T}_{6}(50 \% \mathrm{NPK}+$ $50 \%$ FYM $)(20.81 \mathrm{~g})$ and $\mathrm{T}_{13}(50 \% \mathrm{NPK}+$ $25 \%$ Vermicompost + Biofertilizers) (20.48 g). The minimum water uptake was observed on the $9^{\text {th }}$ day with control (1.27 g) which was significantly lower than the other treatments. The increase in water uptake may be attributed to more sink potential arising out of more number of florets spike ${ }^{-1}$ as well as larger size 
of florets. Increase in post-harvest attributes of cut spikes due to application of integrated nutrient sources could be attributed due to the presence of ethylene inhibitors or due to the presence of cytokinins in organic sources which delayed the senescence of flowers. These results are in corroboration with the findings of Chaudhary et al., (2013) in gladiolus. Also, the increment in water absorption in the spikes harvested from INM treated plots might be due to the fact that the spikes may have greater area of xylem as well as more amounts of carbohydrates resulting in higher water absorption. These results are in accordance with Varu and Barad (2010) in tuberose.

\section{Water loss}

As far as water loss is concerned, it varied significantly with respect to different nutrient sources. A perusal of the data in Table 2 showed that the lowest water loss was obtained on the $9^{\text {th }}$ day with control $(5.71 \mathrm{~g}$ ) which was at par with $\mathrm{T}_{5}$ (Biofertilizers), $\mathrm{T}_{9}$ $(50 \%$ NPK + Biofertilizers $), \quad \mathrm{T}_{3}$ (Vermicompost @ $10 \mathrm{t} \mathrm{ha}^{-1}$ ) and $\mathrm{T}_{2}$ (Pig manure@35 t ha $\left.{ }^{-1}\right)(6.08 \mathrm{~g}, 6.12 \mathrm{~g}, 6.17 \mathrm{~g}$ and $6.25 \mathrm{~g})$ respectively while the highest water loss (17.06 g) was noted with $\mathrm{T}_{12}(50 \% \mathrm{NPK}+$ $25 \%$ Pig manure + Biofertilizers) and it was closely followed by $\mathrm{T}_{11}(50 \% \mathrm{NPK}+25 \%$ FYM + Biofertilizers) (16.95 g). Greater water loss in the integrated nutrient treatments might be due to more surface area for transpiration which has resulted from more number of florets and larger floret diameter.

\section{Water balance ratio}

The data encamped in Table 2 showed that the different nutrient management practices failed to exert significant effect on the water balance ratio under different treatments on all the days of observation. However, the highest water balance ratio (1.263) was registered in $\mathrm{T}_{12}$ $(50 \% \mathrm{NPK}+25 \%$ Pig manure +
Biofertilizers) (1.265) which was at par with $\mathrm{T}_{7}$ (50\% NPK $+50 \%$ Pig manure) while the lowest ratio $(0.224)$ was observed on the $9^{\text {th }}$ day with control followed by $\mathrm{T}_{2}$ and $\mathrm{T}_{3}$ where both the treatments registered a ratio of 0.232 . The obtained results might also be due to the fact that higher water absorption maintained better water balance and flower freshness and vice versa. These results were in accordance with Varu and Barad (2010) in tuberose and Mukesh et al., (2007) in gladiolus.

A perusal of the data in Table 3 indicated that the various nutrient sources did not have significant effect on the days to drooping of $1^{\text {st }}$ floret. However, the maximum days to drooping of the $1^{\text {st }}$ floret was observed in $\mathrm{T}_{12}$ $(50 \%$ NPK $+25 \%$ Pig manure + Biofertilizers) (4.86 days) and the least requirement of days was recorded in control (4.04 days). Data analysis showed that $\mathrm{T}_{12}$ $(50 \% \mathrm{NPK}+25 \%$ Pig manure + Biofertilizers) required the maximum days (8.46) to drooping of $5^{\text {th }}$ floret which showed at par result with $\mathrm{T}_{7}(50 \% \mathrm{NPK}+50 \% \mathrm{Pig}$ manure), $\mathrm{T}_{11}(50 \% \mathrm{NPK}+25 \% \mathrm{FYM}+$ Biofertilizers), $\mathrm{T}_{6}(50 \% \mathrm{NPK}+50 \% \mathrm{FYM})$, $\mathrm{T}_{13} \quad(50 \%$ NPK $+25 \%$ Vermicompost + Biofertilizers) and $\mathrm{T}_{8}(50 \% \mathrm{NPK}+50 \%$ Vermicompost) while control took the least days (6.97) to drooping of the $5^{\text {th }}$ floret which was found to be significantly lower than the rest of the treatments. The obtained results might also be due to a fact that higher water absorption maintained better water balance and flower freshness thus saving the florets from early wilting. These results were in accordance with Varu and Barad (2010) and Mukesh et al., (2007).

\section{Florets remaining open at a time}

The data embodied in Table 3 showed that the treatments had significant effect on the number of florets to remain open at a specific time. 


\begin{tabular}{|c|c|c|c|c|}
\hline \multirow[t]{2}{*}{ Treatments } & \multicolumn{4}{|c|}{ Changes in fresh weight (g) } \\
\hline & $1^{\text {st }}$ Day & $3^{\text {rd }}$ Day & $6^{\text {th }}$ Day & $9^{\text {th }}$ Day \\
\hline $\mathrm{T}_{0}$ & 47.93 & 49.55 & 45.97 & 41.88 \\
\hline $\mathrm{T}_{1}$ & 53.63 & 55.79 & 52.28 & 48.44 \\
\hline $\mathrm{T}_{2}$ & 54.11 & 56.47 & 52.46 & 49.32 \\
\hline $\mathrm{T}_{3}$ & 52.73 & 54.77 & 50.67 & 47.87 \\
\hline $\mathrm{T}_{4}$ & 57.17 & 60.45 & 56.16 & 51.89 \\
\hline $\mathrm{T}_{5}$ & 50.28 & 52.38 & $\mathbf{4 8 . 4 3}$ & 43.93 \\
\hline $\mathrm{T}_{6}$ & 60.98 & 63.45 & 59.00 & 55.13 \\
\hline $\mathrm{T}_{7}$ & 61.22 & 64.05 & 59.27 & $\mathbf{5 5 . 4 7}$ \\
\hline $\mathrm{T}_{8}$ & $\mathbf{5 9 . 4 7}$ & 62.34 & 57.41 & 53.87 \\
\hline $\mathrm{T}_{9}$ & $\mathbf{5 1 . 8 3}$ & 54.25 & 50.57 & 45.85 \\
\hline $\mathrm{T}_{10}$ & 55.78 & 58.91 & 55.31 & 50.81 \\
\hline $\mathrm{T}_{11}$ & 61.74 & 64.72 & 60.08 & 56.75 \\
\hline $\mathrm{T}_{12}$ & 62.45 & 65.37 & 60.98 & 57.43 \\
\hline $\mathrm{T}_{13}$ & $\mathbf{5 9 . 5 4}$ & 62.49 & 59.78 & 55.06 \\
\hline SEm \pm & 1.94 & 2.01 & 1.93 & 1.94 \\
\hline $\mathrm{CD}$ at $5 \%$ & 6.34 & 6.55 & 6.31 & 6.32 \\
\hline
\end{tabular}

Table.2 Water uptake (g), Water loss (g), water balance ratio of cut gladiolus spikes as influenced by pre harvest treatments

\begin{tabular}{|c|c|c|c|c|c|c|c|c|c|}
\hline \multirow[t]{2}{*}{$\mathrm{T}$} & \multicolumn{3}{|c|}{ Water uptake (g) } & \multicolumn{3}{|c|}{ Water loss (g) } & \multicolumn{3}{|c|}{ Water balance ratio } \\
\hline & $\begin{array}{c}3^{\text {rd }} \\
\text { Day }\end{array}$ & $6^{\text {th }}$ Day & $9^{\text {th }}$ Day & $\begin{array}{c}3^{\text {rd }} \\
\text { Day }\end{array}$ & $6^{\text {th }}$ Day & $9^{\text {th }}$ Day & $\begin{array}{c}\mathbf{3}^{\text {rd }} \\
\text { Day }\end{array}$ & $6^{\text {th }}$ Day & $\begin{array}{c}9^{\text {th }} \\
\text { Day }\end{array}$ \\
\hline $\mathbf{T}_{\mathbf{0}}$ & 13.33 & 2.41 & 1.27 & 11.68 & 7.04 & 5.71 & 1.139 & 0.315 & 0.224 \\
\hline $\mathbf{T}_{1}$ & 16.86 & 2.88 & 1.49 & 14.36 & 7.54 & 6.49 & 1.173 & 0.395 & 0.233 \\
\hline $\mathbf{T}_{2}$ & 16.90 & 2.95 & 1.44 & 14.33 & 7.57 & 6.25 & 1.178 & 0.396 & 0.232 \\
\hline $\mathbf{T}_{\mathbf{3}}$ & 16.19 & 2.66 & 1.42 & 13.85 & 7.31 & 6.17 & 1.166 & 0.354 & 0.232 \\
\hline $\mathbf{T}_{4}$ & 18.66 & 3.31 & 1.65 & 15.50 & 8.55 & 6.82 & 1.204 & 0.397 & 0.243 \\
\hline $\mathbf{T}_{5}$ & 14.80 & 2.54 & 1.42 & 12.63 & 7.23 & 6.08 & 1.172 & 0.330 & 0.235 \\
\hline $\mathbf{T}_{6}$ & 20.81 & 3.51 & 1.77 & 16.75 & 8.92 & 6.93 & 1.243 & 0.399 & 0.256 \\
\hline $\mathbf{T}_{7}$ & 20.94 & 3.60 & 1.78 & 16.62 & 9.02 & 7.04 & 1.263 & 0.400 & 0.254 \\
\hline $\mathbf{T}_{8}$ & 19.07 & 3.39 & 1.73 & 15.48 & 8.57 & 6.83 & 1.232 & 0.396 & 0.254 \\
\hline $\mathbf{T}_{9}$ & 16.45 & 2.83 & 1.43 & 13.98 & 8.08 & 6.12 & 1.177 & 0.351 & 0.234 \\
\hline$T_{10}$ & 18.94 & 3.37 & 1.67 & 15.94 & 8.52 & 6.73 & 1.193 & 0.393 & 0.249 \\
\hline$T_{11}$ & 21.26 & 3.64 & 1.77 & 16.95 & 9.07 & 7.04 & 1.258 & 0.403 & 0.251 \\
\hline$T_{12}$ & 21.41 & 3.69 & 1.79 & 17.06 & 9.15 & 7.05 & 1.265 & 0.404 & 0.254 \\
\hline$T_{13}$ & 20.48 & 3.47 & 1.72 & 16.35 & 8.78 & 6.79 & 1.256 & 0.397 & 0.254 \\
\hline SEm \pm & 0.61 & 0.13 & 0.05 & 0.42 & 0.32 & 0.24 & 0.045 & 0.029 & 0.010 \\
\hline CD at $5 \%$ & 1.99 & 0.41 & 0.18 & 1.39 & 1.04 & 0.78 & NS & NS & NS \\
\hline
\end{tabular}




\begin{tabular}{|c|c|c|c|c|}
\hline \multirow[t]{2}{*}{ Treatments } & \multicolumn{2}{|c|}{ Days to drooping } & \multirow{2}{*}{$\begin{array}{l}\text { Florets remaining open at } \\
\text { a specific time }\end{array}$} & \multirow{2}{*}{$\begin{array}{c}\text { Vase life } \\
\text { (days) }\end{array}$} \\
\hline & $1^{\text {st }}$ floret & $5^{\text {th }}$ floret & & \\
\hline $\mathbf{T}_{\mathbf{0}}$ & 4.04 & 6.97 & 5.66 & 9.61 \\
\hline $\mathbf{T}_{1}$ & 4.58 & 7.69 & 5.77 & 10.84 \\
\hline $\mathbf{T}_{2}$ & 4.63 & 7.85 & 5.78 & 10.90 \\
\hline $\mathbf{T}_{\mathbf{3}}$ & 4.49 & 7.47 & 5.72 & 10.50 \\
\hline $\mathbf{T}_{4}$ & 4.76 & 8.15 & 5.98 & 11.67 \\
\hline $\mathbf{T}_{5}$ & 4.41 & 7.35 & 5.71 & 10.20 \\
\hline $\mathbf{T}_{6}$ & 4.73 & 8.41 & 6.29 & 11.97 \\
\hline $\mathbf{T}_{7}$ & 4.84 & 8.45 & 6.33 & 12.19 \\
\hline $\mathbf{T}_{8}$ & 4.70 & 8.32 & 6.09 & 11.74 \\
\hline$T_{9}$ & 4.40 & 7.52 & 5.70 & 10.61 \\
\hline$T_{10}$ & 4.66 & 7.99 & 5.77 & 11.41 \\
\hline$T_{11}$ & 4.84 & 8.44 & 6.33 & 12.39 \\
\hline $\mathbf{T}_{12}$ & 4.86 & 8.46 & 6.34 & 12.51 \\
\hline $\mathbf{T}_{13}$ & 4.67 & 8.38 & 6.13 & 11.87 \\
\hline SEm \pm & 0.17 & 0.24 & 0.13 & 0.36 \\
\hline CD at $5 \%$ & 0.54 & 0.78 & 0.41 & 1.18 \\
\hline
\end{tabular}

A perusal of the data showed that maximum florets to remain open at a specific time was given by $\mathrm{T}_{12}(50 \% \mathrm{NPK}+25 \%$ Pig manure + Biofertilizers) (6.34) followed by $\mathrm{T}_{7}(50 \% \mathrm{NPK}$ $+50 \%$ Pig manure), $\mathrm{T}_{11}(50 \% \mathrm{NPK}+25 \%$ FYM + Biofertilizers), $\mathrm{T}_{6}(50 \% \mathrm{NPK}+50 \%$ FYM $), \mathrm{T}_{13}(50 \% \mathrm{NPK}+25 \%$ Vermicompost + Biofertilizers) and $\mathrm{T}_{8}(50 \% \mathrm{NPK}+50 \%$ Vermicompost). The least florets to remain open at a time was recorded in $\mathrm{T}_{0}$ (5.66) which was found to be at par with other treatments which received single source of nutrients and the integrated treatments consisting of only two sources of nutrients viz. chemical fertilizer and biofertilizers.

\section{Vase life}

Regarding vase life of cut spikes of gladiolus, it is evident from Table 3 that the different treatments varied significantly and it was found that plants grown using integrated nutrient sources resulted in highest number of days to drooping of $70 \%$ florets. A thorough analysis of the data showed that $\mathrm{T}_{12}(50 \% \mathrm{NPK}+25 \% \mathrm{Pig}$ manure + Biofertilizers) gave maximum vase life (12.51 days) which was at par with $\mathrm{T}_{11}$ (50\% NPK + 25\% FYM + Biofertilizers) (12.39 days), $\mathrm{T}_{7}(50 \% \mathrm{NPK}+50 \%$ Pig manure) (12.19 days), $\mathrm{T}_{6}(50 \% \mathrm{NPK}+50 \% \mathrm{FYM})$ (11.97 days) and $\mathrm{T}_{13}(50 \% \mathrm{NPK}+25 \%$ Vermicompost + Biofertilizers) (11.84 days). Control noted the shortest vase life (9.61) followed by $\mathrm{T}_{5}$ (Biofertilizers) (10.20), $\mathrm{T}_{3}$ (Vermicompost @ $10 \mathrm{t} \mathrm{ha}^{-1}$ ) (10.50) and $\mathrm{T}_{9}$ (50\% NPK + Biofertilizers) (10.61). The highest longevity of cut spikes was obtained with the application of $50 \%$ RDF in combination with $25 \%$ pig manure or farmyard manure along with biofertilizers. This might be attributed to consistent and slow release of nutrients throughout the growing period which improved the flowering parameters and ultimately increased the vase life of cut spikes. Increased nutrient uptake by plants in the field condition resulted in greater water conducting tissues during vase life which in turn lead to maintaining turgidity and thus improved the longevity of florets and whole 
spikes. The above results revealed that the post harvest life of cut flower is greatly affected by the pre harvest treatments which are applied in the field. Similar results were also reported by Tripathi et al., (2012) and Ranjan et al., (2014) in tuberose. The obtained results might also be due to the fact that higher water absorption maintained better water balance and flower freshness, saved from early wilting and enhanced vase life. These results were in accordance with Varu and Barad (2010) and Mukesh et al., (2007).

In conclusion, the result of the present investigation thus indicated that for improvement of vase life attributes of Gladiolus primulinus cv. Candyman, integrated application of $50 \%$ recommended dose of fertilizers, 25\% Pig manure along with Azospirillum and Phosphotica is highly beneficial. Almost similar result can also be obtained with the treatments combination of $50 \%$ recommended dose of fertilizers, $25 \%$ FYM along with Azospirillum and Phosphotica.

\section{References}

Bhattacharjee, S. K. and De, L. C. 2010. Gladiolus. Advanced Commercial Floriculture. Revised Edition. Aavishkar Publication, Joipur. 1: 309-310.

Chaudhary, N., Swaroop, K., Janakiram, T., Biswas, D. R. and Singh, G. 2013. Effect of integrated nutrient management on vegetative growth and flowering characters of gladiolus. Indian Journal of Horticulture. 70 (1): 156-159.

Mukesh, K., Vipin, K., Sunil, M. and Lokendra,
K. 2007. Effect of pulsing solutions and stages of spike harvest for refrigerated storage on postharvest quality of gladiolus cut spikes. Journal of Ornamental Horticulture. 10 (1): 25-29.

Panse, V. G. and P. V. Sukhatme. 1989. Statistical Methods for Agricultural Workers. ICAR, New Delhi.

Rajesh, B., Sandeep, D., Dhiman, S. R. and Ritu, J. 2006. Effect of biofertilizers and biostimulants on growth and flowering in standard carnation (Dianthus Caryophyllus Linn.). Journal of Ornamental Horticulture. 9 (4): 282284.

Ranjan, S., Preetham, S. P. and Satish, C. 2014. Effect of organic manures and biofertilizers on vegetative, floral and post harvest attributes in tuberose $\mathrm{cv}$. Shringar. Asian Journal of biological and life sciences. 3 (1): 69.

Singh, J. P., Kumar, K. and Katiyar, P. N. 2012. Effect of zinc, iron and copper on yield parameters of gladiolus. Horticulture Flora Research Spectrum. 1 (1): 64-68.

Tripathi, S. K., Malik, S., Singh, P., Dhyani, B. P., Kumar, V., Dhaka, S. S. and Singh, J. P. 2012. Effect of integrated nutrient management on cut flower production of tuberose (Polianthes tuberosa L.) cv. Suvasini. Annals of Horticulture. 6 (1): 149-152.

Varu, D. K. and Barad, A. V. 2010. Effect of stem length and stage of harvest on vase-life of cut flowers in tuberose (Polianthes tuberosa L.) cv. Double. Journal of Horticultural Sciences. 5 (1): 42-47.

\section{How to cite this article:}

Nini R. Kuotsu, Rokolhuii Keditsu, Laishram Hemanta, K.S. Sabastian and Jonah Dakho. 2018. Vase Life Attributes of Gladiolus primulinus cv. Candyman: Influence of Pre Harvest Treatments. Int.J.Curr.Microbiol.App.Sci. 7(07): 1994-2000. doi: https://doi.org/10.20546/ijcmas.2018.707.235 